\title{
The Nowotwory journal over the last 95 years (1923-2018)
}

\author{
Edward Towpik ${ }^{1,2}$, Wojciech M. Wysocki ${ }^{3}$
}

'The quarterly Nowotwory, its contributing authors and editorial committees have laid down the intellectual foundations of oncology in Poland'.

\section{Launching of the journal and its development}

One of the first global initiatives for publishing a periodical devoted to the fight against cancer arose in Poland back in 1906, when both Dr Mikołaj Rejchmann and Dr Józef Jaworski from Warsaw set up an Anti-Cancer Committee (Komitet do Walki z Rakiem). One of its aims was to launch a journal, however this proved impossible due to the unfavourable conditions prevailing at that time.

When Poland regained its independence, organising anti-cancer policies again became a priority. In July 1921, an Polish Anti-Cancer Committee (Polski Komitet do Zwalczania Raka) in Warsaw came into being. Despite scant resources it rapidly and enthusiastically started its operations. This was reflected by publishing a journal entitled The Bulletin of the Polish Anti-Cancer Committee (Biuletyn Polskiego Komitetu do Zwalczania Raka). The first edition was published in 1923, whose editor was Dr Stefan Sterling-Okuniewski, MD.

At that time, this really was a pioneering endeavour as there were only 5 other such journals dedicated solely to the anti-cancer campaign in the world: the German Zeitschrift für Krebsforschung (1903), the Japanese Gann (1907), the French Bulletin de l'Association Francaise pour l'Etude du Cancer (1909), the Italian Tumori (1911) and from the USA Journal of Cancer Research (1916) ${ }^{1}$. As a comparison, the

\footnotetext{
${ }^{1}$ There were previously at least two journals containing the word 'cancer' in their titles: The New York Quarterly Cancer Journal' (18771880) and Revue des maladies cancéreuses (1895-1901), however none survived the test of time. Our Nowotwory journal has remained as one of the foremost and oldest oncology journals which still appears to this day. The former Zeitschrift für Krebsforschung from 1979 now appears as the Journal of Cancer Research and Clinical Oncology, Gann is today is Cancer Science, the Bulletin de l'Association Francaise pour l'Etude du Cancer appears as Bulletin du Cancer, Tumori is now the Tumori Journal and from 1931, the Journal of Cancer Research
}

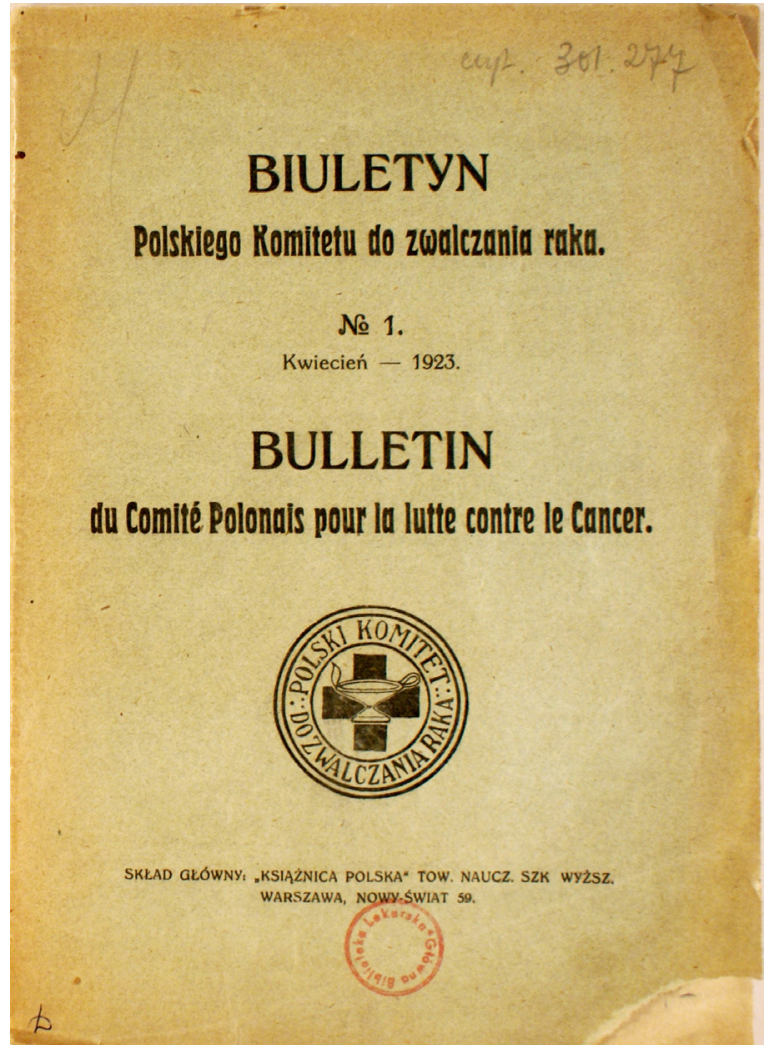

The Bulletin of the Polish Anti-Cancer Committee appeared for the first time in 1923

came out as The American Journal of Cancer which in 1941 again changed its title to Cancer Research.

A paper published in the Polish Nowotwory Journal of Oncology indeed reviewed the oldest ever oncology journals; this being: Mould RF, Aronowitz J, Tiggelen R van, Litten FS. Pierwsze czasopisma naukowe o tematyce onkologicznej — lata 1853-1934 [The first scientific journals on the subject of oncology - 1853-1934]. Nowotwory J Oncol 2007; 57, 4: 442-448.

${ }^{1}$ Maria Skłodowska-Curie Memorial Cancer Centre and Institute of Oncology, Warsaw, Poland

${ }^{2}$ Museum of the History of Medicine, Medical University of Warsaw, Poland

${ }^{3}$ Department of Surgical Oncology, Maria Skłodowska-Curie Memorial Cancer Centre and Institute of Oncology, Kraków

Branch, Poland 


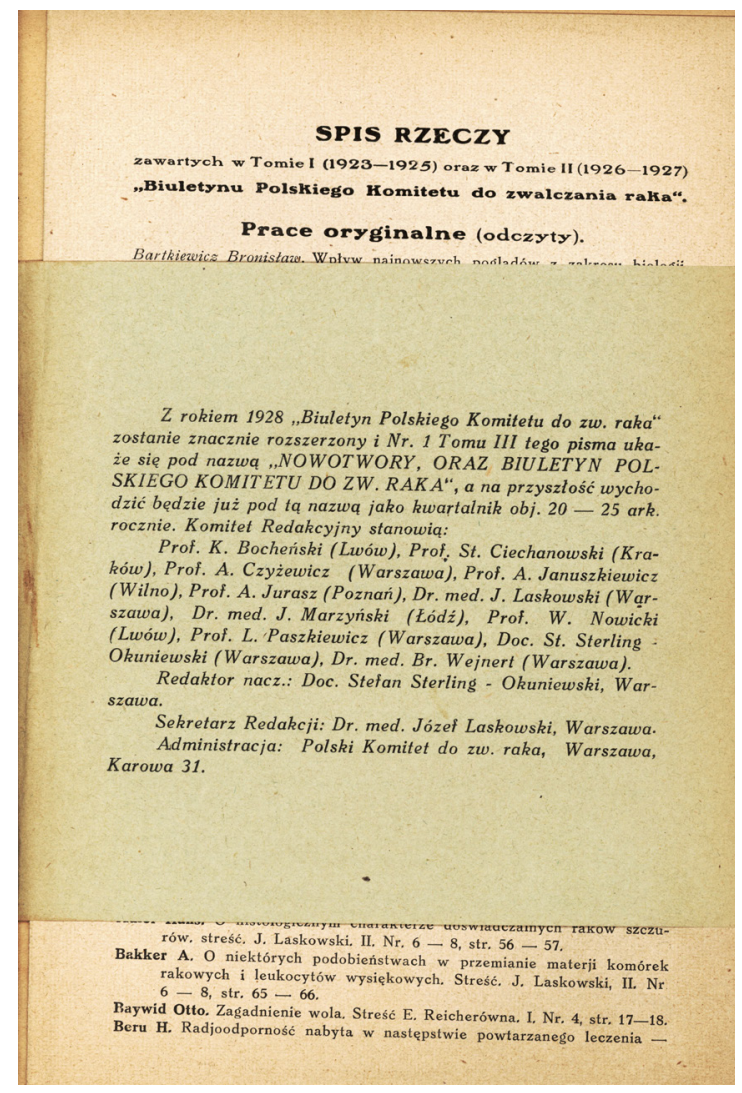

Information regarding the renaming of the Polish Bulletin of the AntiCancer Committee to Nowotwory in 1928

Journal of the National Cancer Institute started in 1940, the British Journal of Cancer in 1947 and Cancer only in 1948.

Editions of the Polish bulletin-journal appeared every 3 months and contained the latest news of the Committee proceedings and data on cancer prevention in Poland and abroad together with cancer reviews. Also included were articles on historically significant events like the 25th anniversary of when radium was discovered or the launching of the Maria Skłodowska-Curie Polish National Gifts Committee which was instrumental in the building of the Warsaw Radium Institute.

Subsequently, a journal arose which consisted of papers devoted to the pathology of various cancers and received the title of Nowotwory (ie. oncology/cancer). This name must have been approved of at that time since from 1928 it has become the proper and permanent title of this journal. The old name of the Bulletin of the Polish Anti-Cancer Committee (Biuletyn Polskiego Komitetu do Zwalczania Raka) has nonetheless been left in the subtitle; thus preserving a continuity of heritage.

Organisational and periodic report-articles were chiefly published in the Bulletin, whereas scientific studies and experimental work began to overtake these in the Nowotwo$r y$. This was a conscious choice of the Editors, who wished to create an ambitious and scientifically par excellence journal. The Nowotwory journal since become a quarterly with excel-

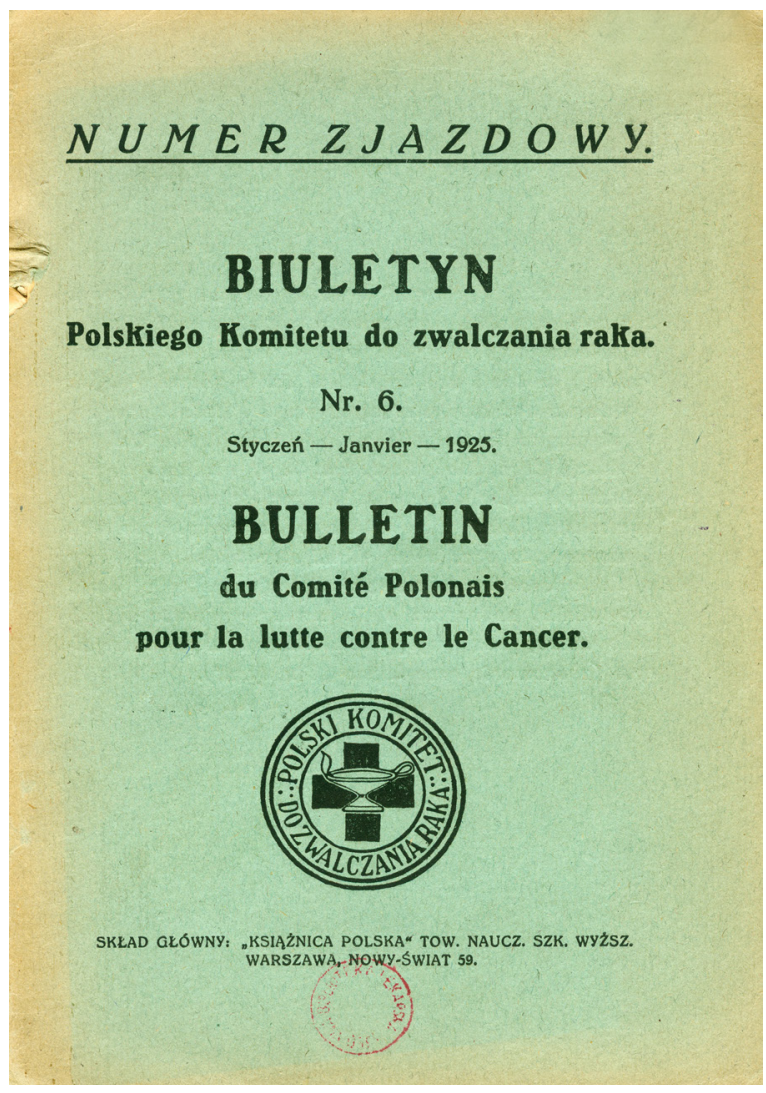

Proceedings of the 1st All-Polish Congress on the Fight Against Cancer in 1925

lent graphic design, printed on chalk paper and some papers having coloured charts, tables and even photo-micrographs. This was all made possible thanks to the generous support of the Count Jakub Potocki Memorial Foundation.

\section{Polish Congresses in oncology and anti-cancer measures}

Polish Congresses have played a key role within the scientific and organisational community for dealing with cancer eradication; they were termed as being 'anti-cancer' during the inter-war years. They took place in 1924, 1929, 1932 and 1936. A special edition of the Bulletin of the meeting proceedings were published, and later by the Nowotwory.

In December 1924, an All-Polish Congress on the Fight Against Cancer took place in Warsaw. A special edition of the Bulletin was thus published as a commemoration of this event (No. 6) that described the proceedings and resolutions made.

These resolutions significantly impacted on the development of anti-cancer measures taken in Poland leading to the Nowotwory being eventually published. At that time the Nationwide Anti-Cancer Committee was established in Poland together with a Cancer Research Sector as launched by the Polish Association of Physicians and Biologists. 


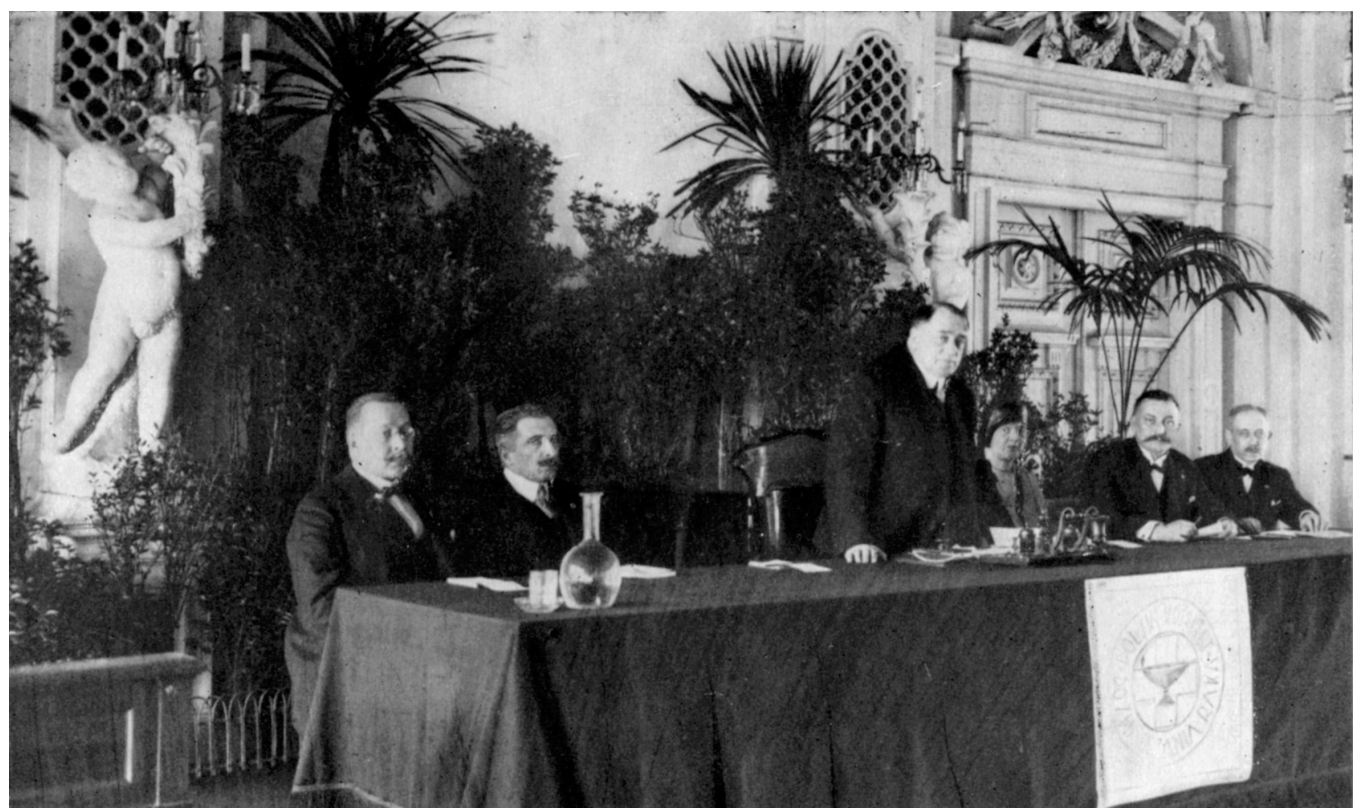

Opening of the Second Anti-Cancer Congress at the City Hall Council in Warsaw's Theatre Square, 1929

In 1929, a Second Anti-Cancer Congress took place in Warsaw, at the City Hall Council on Theatre Square. The grand opening was made by the Honorary President of the Polish Anti-cancer Committee; the then Minister of Public Health, Dr Witold Chodźko.

The wife of the President of the Polish Republic was present (the Right Honourable Michalina Mościcka), who was the chairwoman of the Women's Circle from the Polish Anti-Cancer Committee; her deputies being the wife of Marshal Piłsudski (Aleksandra Piłsudska) and wife of the vice-president of the Committee (Maria Wejnertowa).
The Nowotwory reported that 250 persons attended and that 14 papers were presented. Amongst other things, the final congress resolution propounded to establish a cancer control section at the Health Service Department, to create shelters for terminally ill patients, the setting up of radiology departments in existing hospitals and clinics along with completing the building of the Warsaw Radium Institute as soon as possible.

In 1932, the Nowotwory published a separate edition commemorating the Third Nationwide Anti-Cancer Congress held in Łódź with about 400 persons attending and 32 papers being presented.

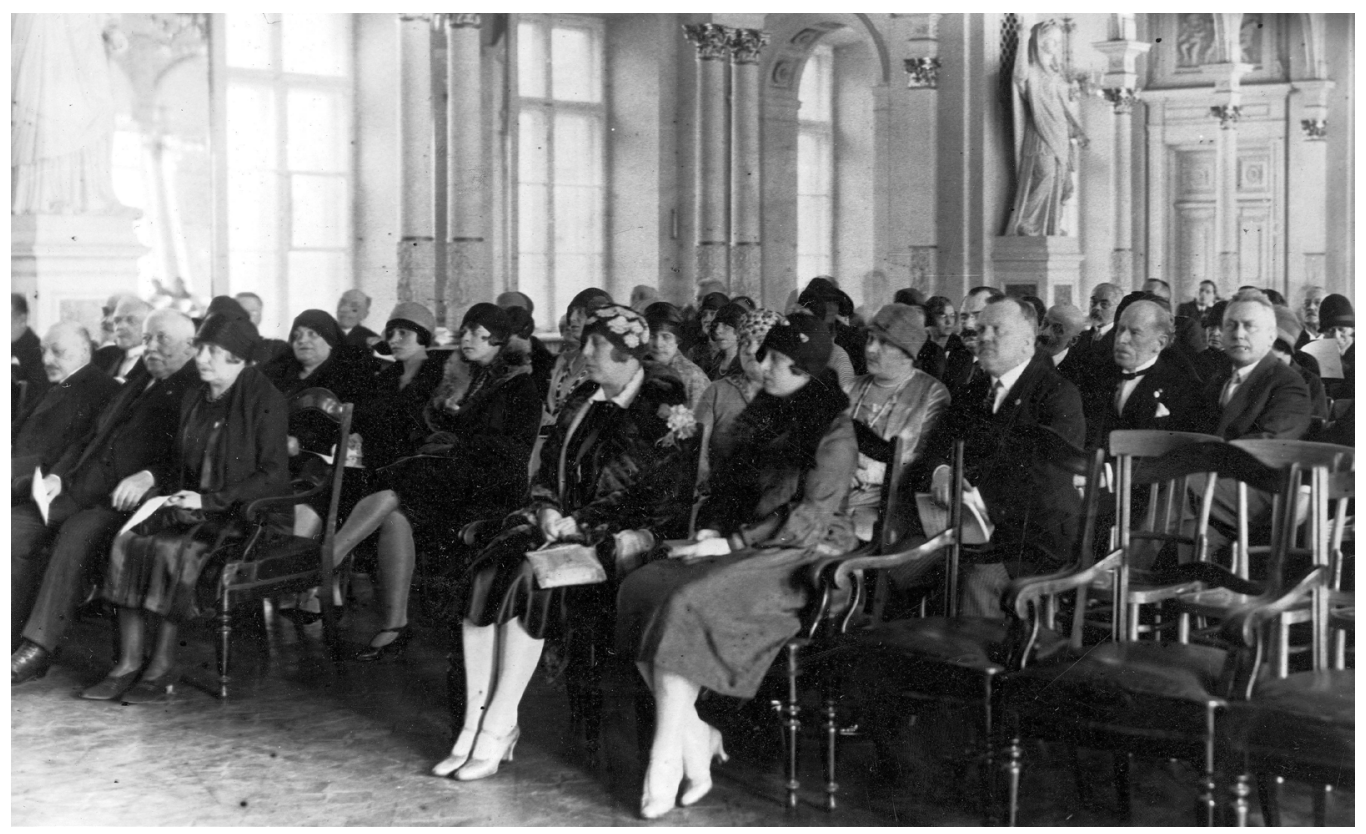

The Council Chamber for the Second Anti-Cancer Congress 


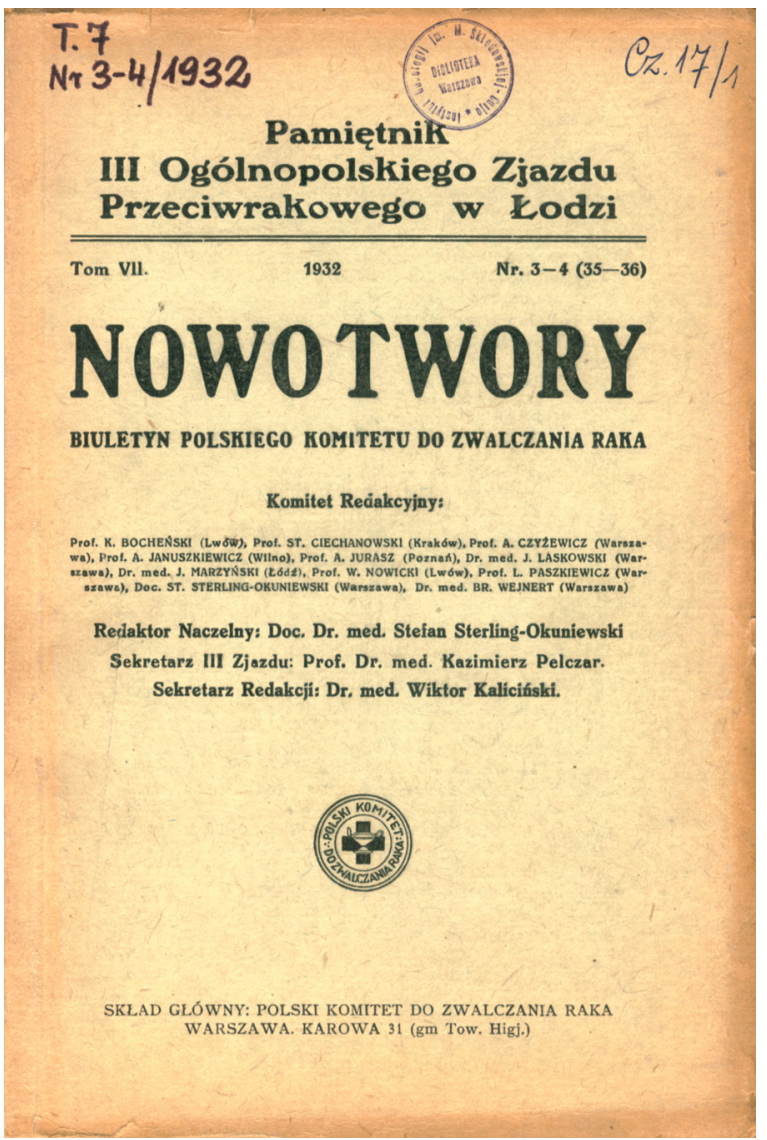

In a separate volume of the Nowotwory the proceedings from the 3rd National Anti-Cancer Congress in Łódź (1932) were published

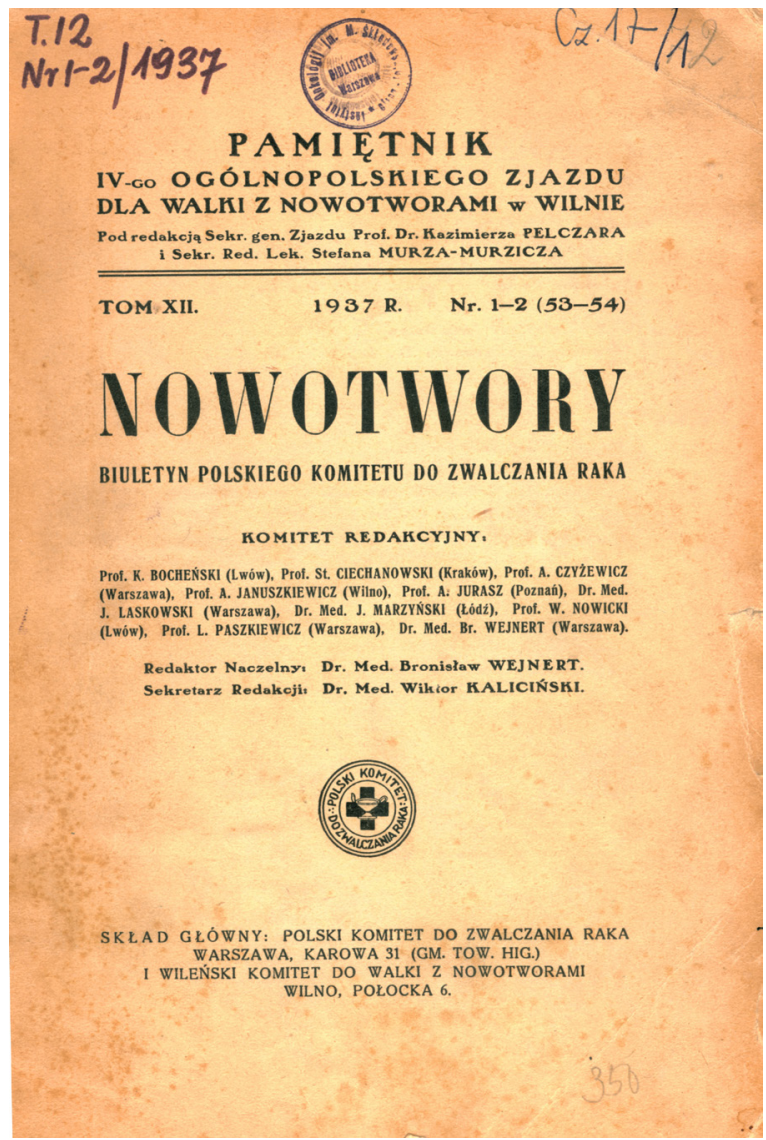

Proceedings of the Fourth National Anti-Cancer Congress from Vilnius in 1936

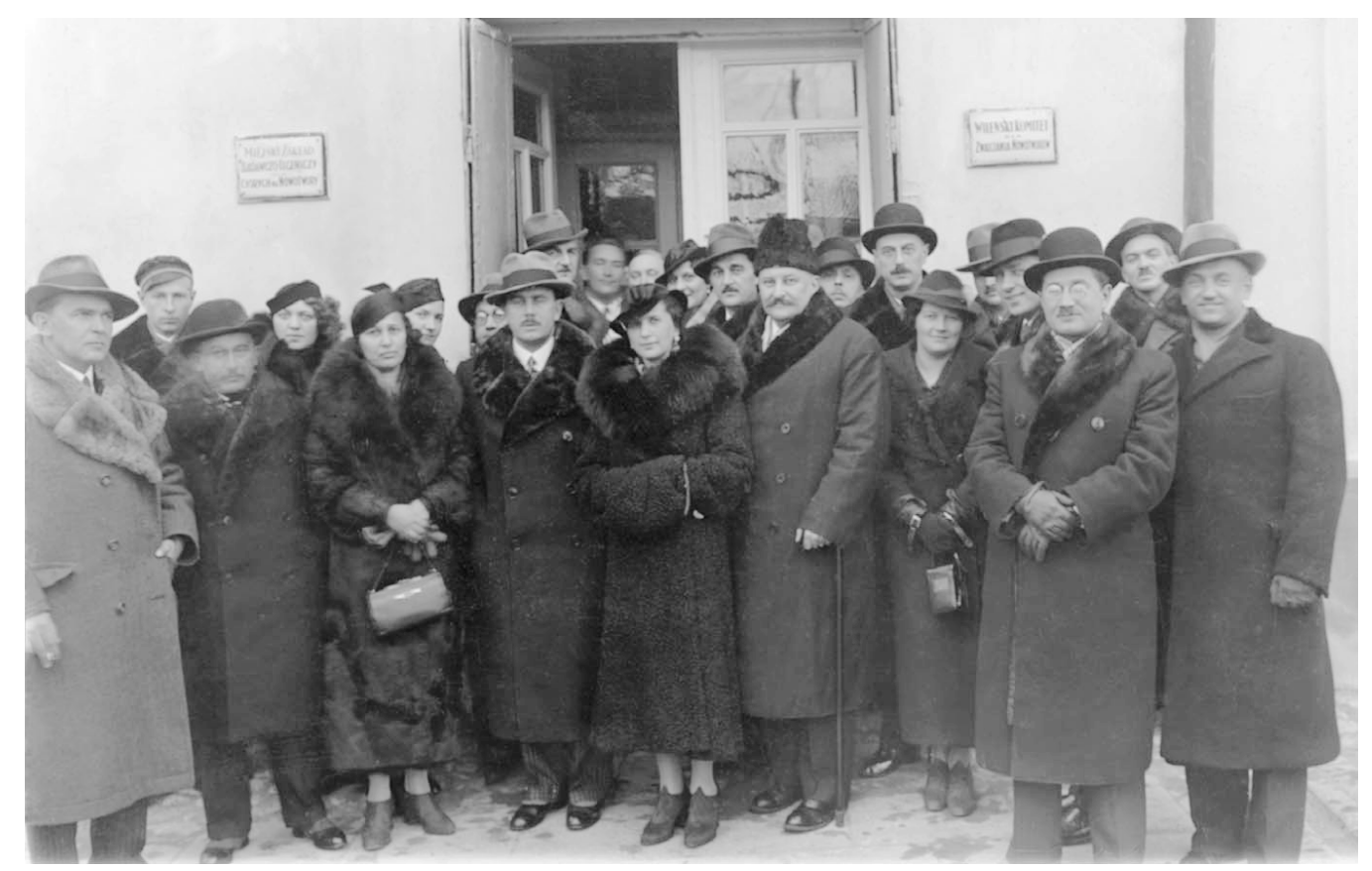

Participants of the IV National Anti-Cancer Congress in Vilnius 
At that time a project was proposed to create an All-Slavic Anti-Cancer League that included the nations of Czechoslovakia, Yugoslavia, Bulgaria and Poland, whilst the Nowotwory was to be transformed into a Slavic journal entitled Acta Slavica Neoplasmatica. This project however never materialised.

In 1937, the Nowotwory's editors published a special issue (volume 1/2 of volume XII) commemorating the Fourth National Anti-Cancer Congress held in Vilnius, which took place on December 6th-8th, 1936.

The proceedings were edited by the General Secretary of the Congress, Professor Kazimierz Pelczar. Many valuable and interesting findings were reported in the Nowotwory volume, describing the major achievements of the interwar period within the oncological field. The congress was held in 6 sections. The final conclusions of the Vilnius Convention called for organising special treatment facilities for cancer patients, unifying cancer treatment methods throughout the country, providing cancer training to doctors and incorporating lectures on this subject area into the curriculum for medical students.

\section{Editoral Committee}

Because of the increasing influx of editorial works on diverse subjects, it became necessary to expand the editorial board of the Nowotwory Editors and to create an Editorial Committee. This committee was constituted in 1930 and made up of the following persons:

- Professor Kazimierz Bocheński; Head of the Obstetric and Gynaecological Clinic at the Jan Kazimierz University in Lviv.

- Professor Stanislaw Ciechanowski; Head of the Pathological Anatomy Chair at the Jagiellonian University in Kraków.

- Professor Adam Czyżewicz; Head of the Obstetrics and Gynaecological Clinic at the Józef Piłsudski University in Warsaw.

- Professor Aleksander Januszkiewicz; Head of the Internal Medicine Department at the Stefan Batory University in Vilnius.

- Professor Antoni Jurasz; Head of the Surgical Clinic at the University of Poznań.

- Dr Józef Laskowski; Head of the Pathology Laboratory at the Radium Institute in Warsaw.

- Dr J. Marzynski from Łódź.

- Professor Witold Nowicki; Head of the Pathological Anatomy Chair at the Jan Kazimierz University in Lviv.

- Professor Ludwik Paszkiewicz; Head of the Pathological Anatomy Chair at the Józef Piłsudski University in Warsaw.

- Dr Bronisław Wejnert from the Polish Anti-Cancer Committee.
Here follows some shortened biographies of the Editors-in-chief and Editorial Secretaries.

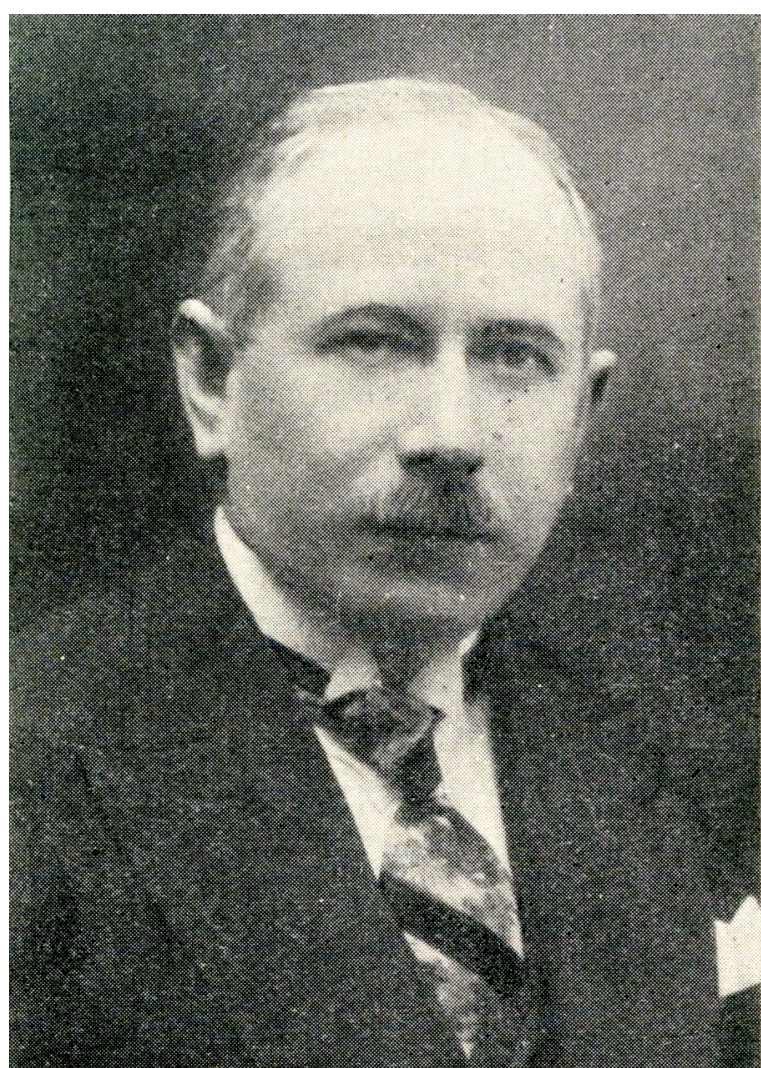

Dr Stefan Sterling-Okuniewski; the first Editor in 1923-34

Dr Stefan Sterling-Okuniewski, MD, PhD (1884-1934)

For engaging in movements for Polish independence, he was expelled from studying at the Faculty of Medicine at the Imperial University of Warsaw in 1904. He instead, he obtained his doctorate in medicine (MD) and doctor of philosophy (PhD) in Zurich and Wroclaw. In 1918, he created the first Anticancer Clinic in Łódź, Poland. In 1924, he obtained his DSc (habilitation) and from 1928 onwards he was appointed head of the Ujazdowski Hospital in Warsaw. In 1921 he was a co-founder of the Polish Anti-Cancer Committee and later became one of its most deserved and most active members. Right from the outset in 1923, he was the editor of the Bulletin, and then the Nowotwory, where he made outstanding contributions to the journal's development. As a member on the Board of the Polish Anti-Cancer Committee, he played a leading role in organising the anti-cancer congresses and exhibitions. Up until the last moments of his life he managed the Editorial Office, always displaying an uncommon energy, diligence and erudition.

After the death of Dr Sterling-Okuniewski in 1934, Dr Bronislaw Adam Wejnert, MD, (1880-1946) became the editor of the Nowotwory up until the outbreak of World War II. 


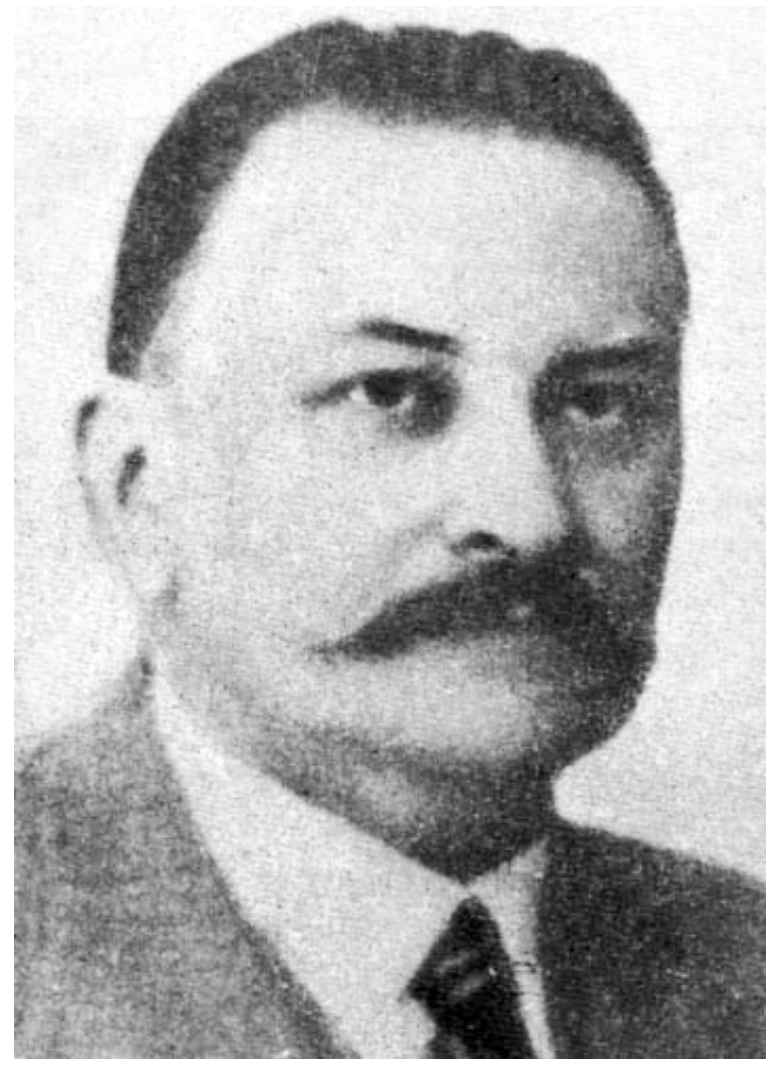

Dr Bronisław Wejnert; the Editor during 1934-39

He graduated in medicine at the University of Dorpat in 1906. In 1921, he was one of the founders of the Polish Anti-Cancer Committee and was its vice-president until 1939. He was the curator of the first cancer patient clinic in Warsaw. He propounded creating a divisional structure for treating cancer patients and organising healthcare for terminally ill patients. Dr Wejnert made outstanding contributions in organising the four anti-cancer meetings in Poland during 1924-1936 and he was also an active member on the Building Committee of the Maria Skłodowska-Curie Memorial Radium Institute in Warsaw.

Professor Dr. Józef Hornowski (1874-1923), was an excellent anatomical pathologist, who actively participated in the work of the Polish Anti-Cancer Committee as the chairman of scientific meetings, lecturer and editor of papers published in a special edition of the Bulletin entitled Nowotwory.

During 1902-1907 he worked at the Transformational Medicine Hospital in Warsaw. In 1914 he received the Chair of Pathological Anatomy in Lviv, and in 1919 became the director of the Department of Pathological Anatomy at the University of Warsaw. He was a member of the National Health Council and the Polish Academy of Learning.

During 1928-29, the secretary of the Editorial Staff was a pathologist, Dr Józef Laskowski (1900-1970). Since when the Radium Institute was founded, he worked as the head

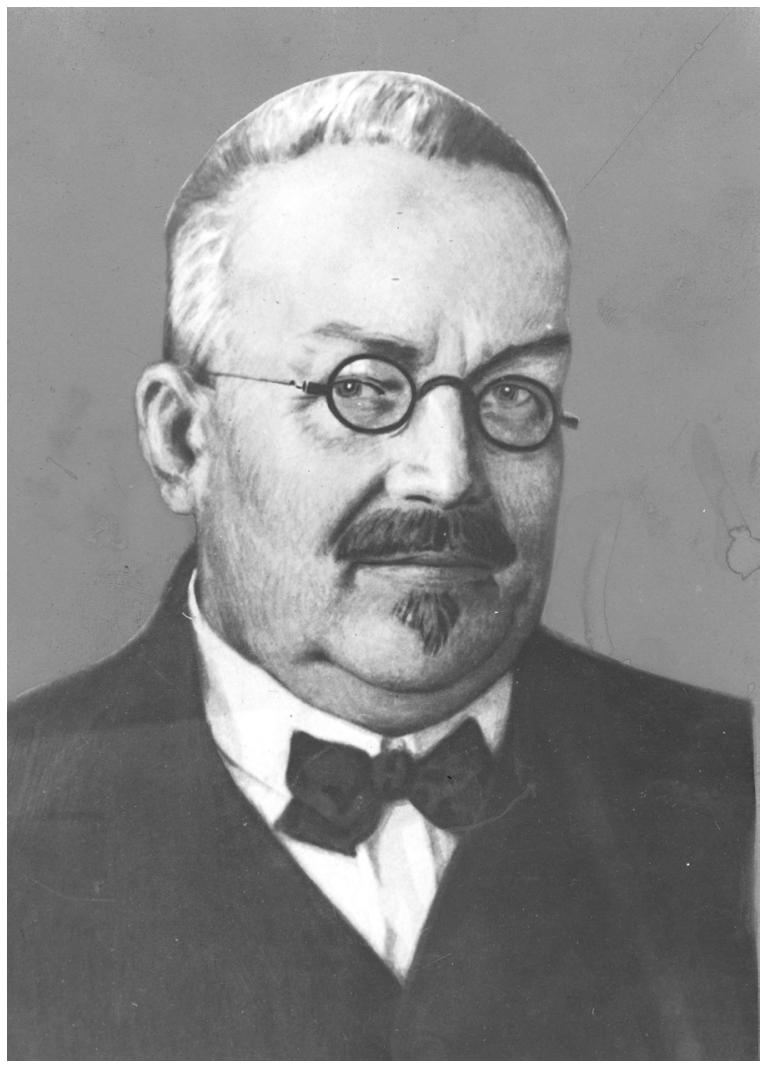

Professor Józef Hornowski - editor of the first issue of the Bulletin under the title of Nowotwory

of the Histopathology Laboratory for 38 years and during 1956-61 he was the Institute's director. Amongst his achievements, he set up the Polish school for clinical histology and pioneered introducing the oligobiopsy method to Poland. He was also a member of the Polish Academy of Learning and the Polish Academy of Sciences along with being the first Honorary Member of the Polish Oncological Society.

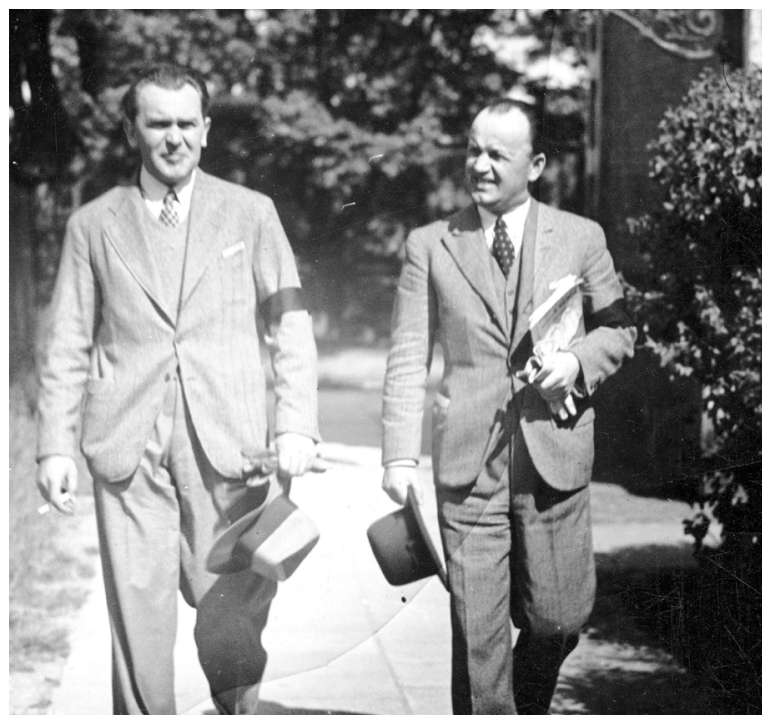

Dr Józef Laskowski (left) Secretary to the Editorial Office in 1928-29 and Dr Wiktor Kalicinski (right) - Secretary to the Editorial Office in 1929-1939 
From 1929 until the outbreak of the war, the secretary of the editorial team was Dr. Wiktor Kaliciński (1896-1940), a pathologist, soldier of the Polska Organizacja Wojskowa (Polish Military Organisation) and of the First Legion Brigade who fought in the Polish-Soviet war of 1920.

He was the Department Head of Pathology at the Ujazdowski Hospital and Major in the Polish Army. Being an honoured legionnaire and of impeccable trust he, together with Józef Laskowski, embalmed the body of Marshal Piłsudski upon his death in 1935. He had been an active member of the Polish Anti-Cancer Committee over many years. During the war he was a Soviet prisoner in Kozielsk and then murdered by the NKVD in Katyń.

\section{Summing up the inter-war period}

During 1923-38, thirteen volumes of the Nowotwory journal were published as follows:

$\begin{array}{lll}\text { Volume I } & \text { (No. 1-8) } & -1923-1925 \\ \text { Volume II } & \text { (No. 9-16) } & -1926-1927\end{array}$

Volume III

(No.17-20)

$-1928-1929$

Volume IV

(No. 21-24)

$-1929-1930$

Volume V

(No. 25-28)

$-1930$

Volume VI

(No. 29-32)

$-1931$

Volume VII

(No. 33-36)

$-1932$

Volume VIII

(No. 37-40)

$-1933$

Volume IX

(No. 41-45)

$-1934$

Volume X

(No. 45-48)

$-1935$

Volume XI

(No. 49-52)

$-1936$

Volume XII

(No. 53-56)

$-1937$

Volume XIII

(No. 57-60)

$-1938$

Publication of Volume XIV was interrupted by the outbreak of World War II.

A list of the most important works published in the Bulletin of the Polish Anti-Cancer Committee is provided below together with those from the Nowotwory during 1923-1938 according to a selection made by Professor Witold Rutkowski.
1. Raczynski SM. On the fight against cancer [W sprawie walki z rakiem]. Biul Pol Kom Zwalcz Raka 1923; 1: 6-27.

2. Hornowski J. On defining the terms 'cancer' and 'sarcoma' [W sprawie nazw "rak" $i$ „mięsak”]. Biul Pol Kom Zwalcz Raka 1923; 2, 1: 5-6.

3. Paszkiewicz L. Carcinogenicity of coal tar [O rakotwórczym działaniu smoły pogazowej]. Biul Pol Kom Zwalcz Raka 1923; 2, 1: 7-29.

4. Skubiszewski L. Thyroid cancer [Nowotwory tarczycy]. Biul Pol Kom Zwalcz Raka 1923; 2, 1: 30-46

5. Dabrowski J. Comments on tumours and neoplasms of the haematopoietic system based on the observed hypertrophy in the reticuloendothelial system [Kilka uwag o nowotworach i nowotworzeniach w układzie krwiotwórczym na podstawie spostrzeganego przypadku przerostu układu siateczkowo-śródbłonkowego]. Biul Pol Kom Zwalcz Raka 1923; 2, 1:47-60.

6. KowalskiW. The significance of tumour phylogenesis in epulis congenita formation [Znaczenie filogenezy w powstawaniu nowotworów w związku z epulis congenita]. Biul Pol Kom Zwalcz Raka 1923; 2, 1: 47-60.

7. Czarnocki W. Comments on thymomas based on cases of thymoma malignum [Kilka uwag o nowotworach grasicy na podstawie spostrzeganego przypadku grasiczaka złośliwego (thymoma malignum)]. Biul Pol Kom Zwalcz Raka 1923; 2, 1: 80-95.

8. Wusatowski J. Primary liver cancer [Pierwotny rak wątroby]. Biul Pol Kom Zwalcz Raka 1923; 2,1: 80-95.

9. Siedlecka A. Sarcoma primitivum pulmonis (Primary pulmonary sarcomas/Connective tissue sarcomas) [Sarcoma primitivum pulmonis (łącznotkankowiec złośliwy, mięsak)]. Biul Pol Kom Zwalcz Raka 1923: 2, 1: 96-102.
10. Poltorzyczka St. Causes of carotid body tumours (paragangliomas) [Przyczynek do nowotworów złośliwych z kłębka szyjnego]. Biul Pol Kom Zwalcz Raka 1923: 2, 1: 103-108.

11. Wejnert B. Comparing cancer to other diseases of the gastro-intestinal tract [Rak w stosunku do innych chorób przewodu pokarmowego]. Biul Pol Kom Zwalcz Raka 1923; 8: 42-45.

12. Grundzach I. Cancer and vitamin biology [Rak a nauka o witaminach]. Biul Pol Kom Zwalcz Raka 1923; 8: 36-41.

13. Mikalszewski W. Statistical sampling of cancer cases in Poland. Chapter I [Próba statystyki nowotworów złośliwych w Rzeczypospolitej Polskiej — rozdział I]. Biul Pol Kom Zwalcz Raka 1923; 8: 3-11.

14. Bartkiewicz B. The impact of the latest developments in cancer biology on patient treatment; present and future [Wpływ najnowszych poglądów z zakresu biologii raka na leczenie jego teraz i w przyszłości]. Biul Pol Kom Zwalcz Raka 1923; 8: 17-36.

15. Jakubowicz H. Assessing the value of the Botelho reaction in diagnosing cancer [O wartości odczynu Bothelo w diagnostyce raka]. Biul Pol Kom Zwalcz Raka 1924; 4: 8-12.

16. Czyżewicz A. The treatment of cancer with radium [O leczeniu nowotworów radem]. Nowotwory 1929: 4, 1: 48-73.

17. Hirszfeld L, Halberowna W \& Laskowski J. Assessing the serologic properties of normal and cancerous tissues [O własnościach serologicznych tkanki normalnej i rakowej]. Nowotwory 1929; 4, 1: 98-100.

18. Eiger M. Assessing Interferometry [O badaniach interferometrycznych]. Nowotwory 1929: 4, 1: 100-113.

19. Eiger M \& Czarnecki E. The effect of autonomic nervous system function on experimental tumourigensis [Wpływ układu nerwowego mimowolnego na powstawanie nowotworów doświadczalnych]. Nowotwory 1929; 4, 1: 113-121. 
20. Floksztrumpf M, Kolodziejski J \& Milewski. Modern methods that use lead for treating cancer [Współczesne leczenie ołowiem nowotworów złośliwych]. Nowotwory 1929; 4, 1: 153.

21. Floksztrumpf M. Three-year outcomes of using radium for treating gynaecological cancers [Wyniki trzyletniego stosowania radu w nowotworach złośliwych narządów rodnych kobiet]. Nowotwory 1929; 4, 1: 144-153.

22. Flaks J. Thyroid effects on sarcoma growth in rats [Wpływ tarczycy na wzrost mięsaka szczurzego]. Nowotwory 1929; 4, 1: 122-144.

23. Pelczar K. Courses of the immune response during cancer [O przebiegu niektórych odczynów odpornościowych w raku]. Nowotwory 1929; 4, 1: 97.

24. MiklaszewskiW. Statistical sampling of cancers in Poland [Próba statystyki nowotworów złośliwych w Rzeczypospolitej Polskiej]. Nowotwory 1929; 4, 2: 188-216; 384-402.

25. Pruszczynski A. Epithelial testicular cancer from sperm stem cells [Nabłonkowiec złośliwy jądra z komórek macierzystych plemników]. Nowotwory 1929; 2: 155-172.

26. Stein J. Concerning biliary structures; Xanthomas [O tworach żółciakowych (Xanthomata)]. Nowotwory 1929; 4, 2: 172-188; 3, 272-289.

27. Kalecka R. Variations in blood cholesterol levels observed in cancer patients undergoing X-rays [Wahania poziomu cholestryny we krwi u chorych na raka pod wpływem promieni Röntgena]. Nowotwory 1929; 4, 3: 263-271.

28. Grynkraut $B$. Factors governing tumourigenesis, tuour Ifetime and treatment [O czynniku w powstawaniu, życiu i leczeniu nowotworów]. Nowotwory 1929; 4, 3: 249-262.

29. Wejnert B. Cancer prevention medicine [Medycyna zapobiegawcza w raku]. Nowotwory 1929; 4, 4: 293-304.

30. Eiger M, Czarnecki E. Experimental research on tumours [Badania nad nowotworami doświadczalnymi]. Nowotwory 1929; 4, 4: 331-380.

31. Sterling-Okuniewski S. The association of lung sarcoma with tuberculosis and syphilis [Skojarzenie mięsaka płuca z gruźlicą i kiłą]. Nowotwory 1931; 6, 1: 10-17.

32. Stein J. About chlormat [O chlormacie]. Nowotwory 1931; 6, 2: 80-97; 3-4: 159-173.

33. Schlnvogt E. Pancreatic cystadenoma [Gruczolak torbielowaty trzustki]. Nowotwory 1931; 6: 3-4, 145-158.

34. Kosieradzki K. Cancer in young animals [W sprawie raka u osobników młodych]. Nowotwory 1931; 6, 2: 106-120; 3-4: 193-222.

35. Karnicki W. Endocrine gland function on the formation and behaviour of experimental tumours [Wpływ gruczołów dokrewnych na powstawanie i zachowanie się nowotworów doświadczalnych]. Nowotwory 1931; 6, 2: 98-105;3-4: 174-192.

36. Tur J. Studies on embryonic tumours [Studia nad nowotworami u zarodków]. Nowotwory 1935; 10, 1-4: 1-115.

37. Hirszfeld L. Theoretical basis for tumour serodiagnosis [Podstawy teoretyczne serodiagnostyki nowotworów]. Nowotwory 1936; 11, 1-4: 3-24.

38. Chodkowska S. A case of a malignant gallbladder hybrid [Przypadek złośliwego mieszańca pęcherzyka żółciowego]. Nowotwory 1936; 11, 1-4: 25-34.
39. Floksztrumpf M. Long-term outcomes of treating rectal carcinomas with radium [Odległe wyniki leczenia raków odbytnicy radem]. Nowotwory 1936; 11, 1-4: 35-41.

40. Nielipinski W. The importance of well-being in cancer patients [Rola konstytucji u chorych na nowotwory złośliwe]. Nowotwory 1938; 13, 1: 7-24.

41. Wodziński M. Primary intestinal sarcomas [O pierwotnych mięsakach jelit]. Nowotwory 1938; 13, 1: 35-65.

42. Kasprzyk M. Recognising the significance of tumour fibres [Włókna kratkowe w nowotworach i ich znaczenie rozpoznawcze]. Nowotwory 1938; 13: 1, 67-92.

43. Dmochowski L. A review of Freund's therapeutic method in cancer [O metodzie leczniczej Freunda w schorzeniu rakowym]. Nowotwory 1938; 13, 1: 93-101.

44. Osuchowski M. Nationwide cancer patient statistics and other malignancies for the Polish Republic in 1935 [Statystyka chorych na raka i inne nowotwory złośliwe $z$ obszaru całej Rzeczypospolitej Polskiej za rok 1935]. Nowotwory 1938; 13, 1: 103-116.

45. Dmochowski L. Experimental investigations of haematopoietic cancers; Brown-Perce's cancer in rabbits and Murray-fatoma in guinea pigs [Badania doświadczalne nad nowotworami zwierzęcymi przeszczepialnymi — rakiem Brown-Perce'a u królików i mięsako-tłuszczakiem Murraya u świnek morskich]. Nowotwory 1936; 13, 2: 129-182.

46. Gottlieb G, Spritzer M, Taschner E. Studies on the general effects of carcinogenic bodies [Badania doświadczalne nad ogólnym działaniem ciał rakotwórczych]. Nowotwory 1938; 13, 2: 183-201.

47. Stolyhwowa E, Nielipinski W. Studies on the correlation between cancer localisation and racial type [Z badań nad współzależnością lokalizacji raka, a typem rasowym]. Nowotwory 1938; 13, 2: 203-238.

48. Zakrzewski Z. Issues concerning cancer resistance [Zagadnienia odporności nowotworów złośliwych]. Nowotwory 1938; 13, 3-4: 257-330.

49. Laskowski J. Special forms of squamous cell carcinoma reviewed [O szczególnych postaciach raka płaskonabłonkowego]. Nowotwory 1938; 13, 3-4: 331-342.

50. Stein J. The effects of immune cytotoxic sera and normal xenobiosis on tissue cultures in vitro [O wpływie odpornościowych surowic cytotoksycznych oraz normalnych surowic obcogatunkowych na hodowle tkanek in vitro]. Nowotwory 1938; 13, 3-4: 343-383.

51. Sosin J. Experiences of Jensen's sarcoma: its height and immunity issues [ $Z$ doświadczeń z mięsakiem Jensena: jego wzrost i sprawa odporności]. Nowotwory 1938; 13, 3-4: 385-404.

52. Stein J. Histiogenesis and the nature of papillary carcinomas [W sprawie histiogenezy oraz istoty guzów brodawczakowatych wsierdzia]. Nowotwory 1938; 13, 3-4: 405-448.

53. Grodzienski E. Disseminated bone turnover in the clinic [Z kliniki rozsianego zrakowacenia kostnego]. Nowotwory 1938; 13, 3-4: 449-460.

54. Zebrowski A. Some remarks on experimental cancer in Brown-Wade-Pearce rabbits [Kilka uwag o raku doświadczalnym królików typu Brown-Wade-Pearce]. Nowotwory 1938; 13, 3-4: 461-468. 


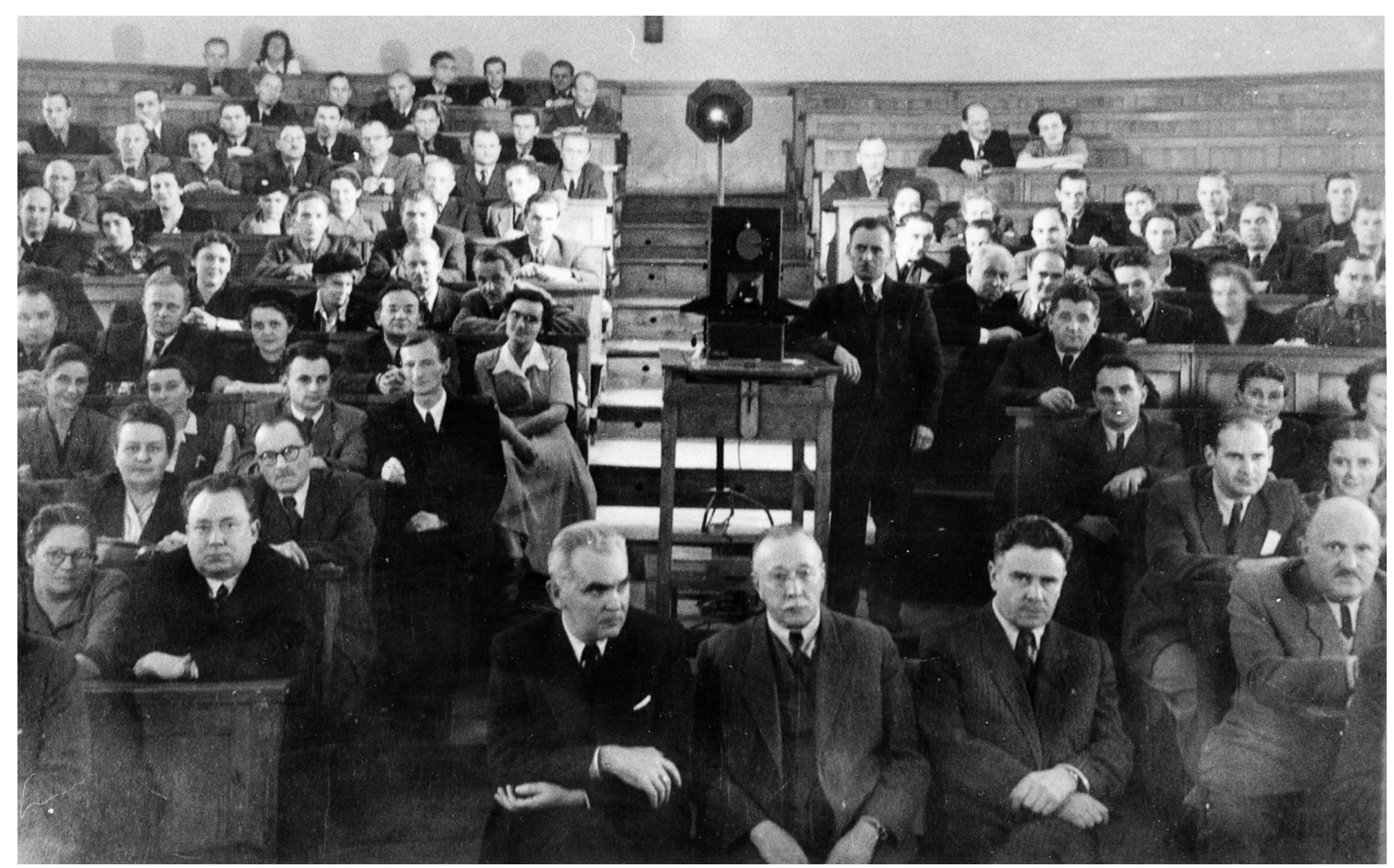

The first post-war Anti-Cancer Congress, November 1949. In the foreground: prof. Józef Laskowski, prof. Ludwik Paszkiewicz and prof. Franciszek Łukaszczyk; in the second row — the second from the right — Dr Tadeusz Koszarowski

\section{The post-war period}

The first post-war volume of the Journal of Oncology reappeared in 1950.

It featured the collective works from an Anti-Cancer Congress that took place a year earlier in Warsaw. Over the next five years, the journal was issued annually as a single volume. In 1952, the editors' address was published for the first time: Institute for Oncology, 15 Wawelska Street.

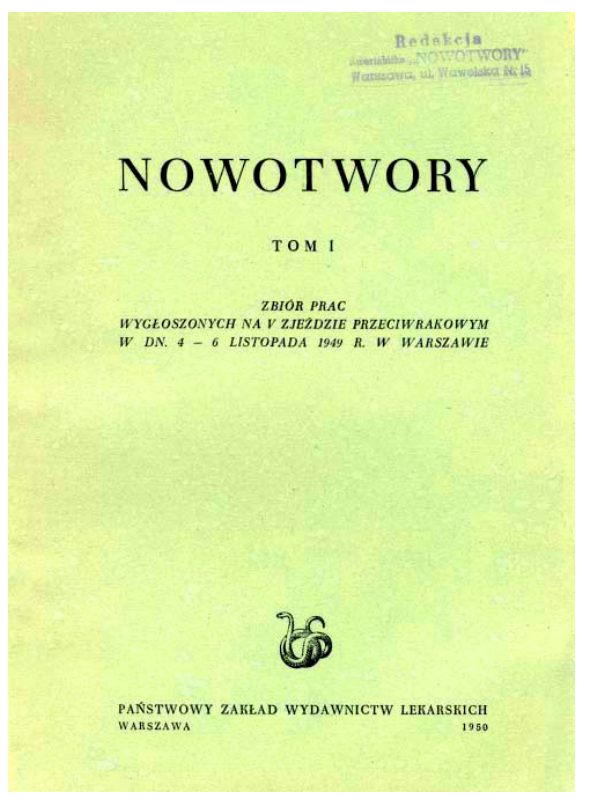

The first post-war journal (and also the yearbook) was published in 1950
In 1956, the journal became a quarterly. The following subtitle was inserted:'Organ of the Maria Skłodowska-Curie Memorial Cancer Center and Institute of Oncology and the Polish Society of Oncology. In 1957, as a result of the 'post-October thaw', the insignia of the former Polish Anti-Cancer Committee was allowed to embellish the journal cover for the first time; now as the insignia of the Polish Society of Oncology.

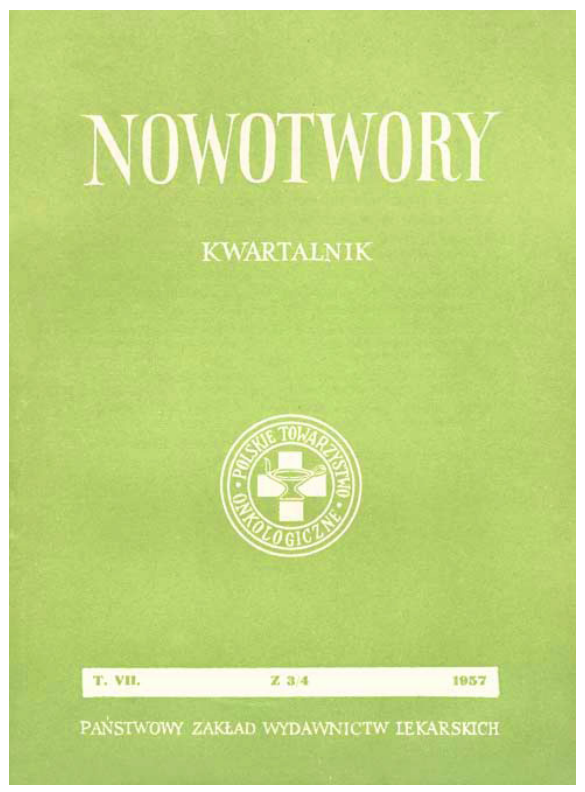

In 1956, the subtitle relates that the journal is a body of the Polish Oncological Society and the Institute of Oncology and are furnished for the first time with the emblem of the pre-war Polish Committee for Cancer; now termed the Polish Oncological Society 
At that time, these were significant developments because in the preceding Stalinist period, all the pre-war medical associations had been discontinued.

During 1950-56 the Journal of Oncology was edited by Dr Franciszek Łukaszczyk (1897-1956), who was the director of the Radium Institute from 1932, a scholar of the Curie Foundation in Paris and a student of Claud Regaud who had founded the school for clinical oncology in Poland.

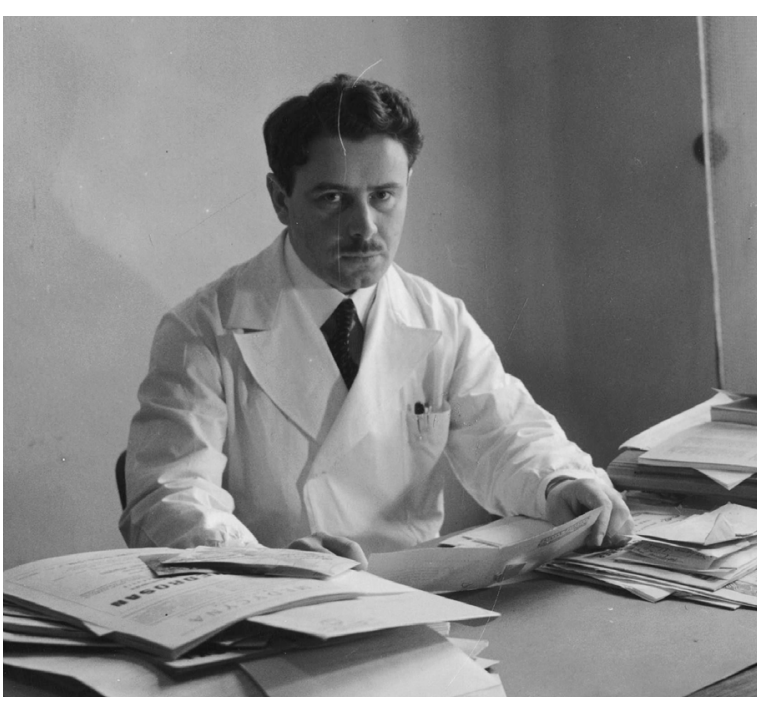

Dr Franciszek Łukaszczyk resumed publishing the journal after the war and was its editor during 1950-56

After the war, he became chairman of the Polish Oncological Society and a member of the Polish Academy of Learning.

For the next 18 years after his death, the journal was headed by Profesor Witold Rudowski (1918-2001), who was a member of the first post-war surgical team at the Radium Institute as well as then being the institute's long-term scientific secretary.

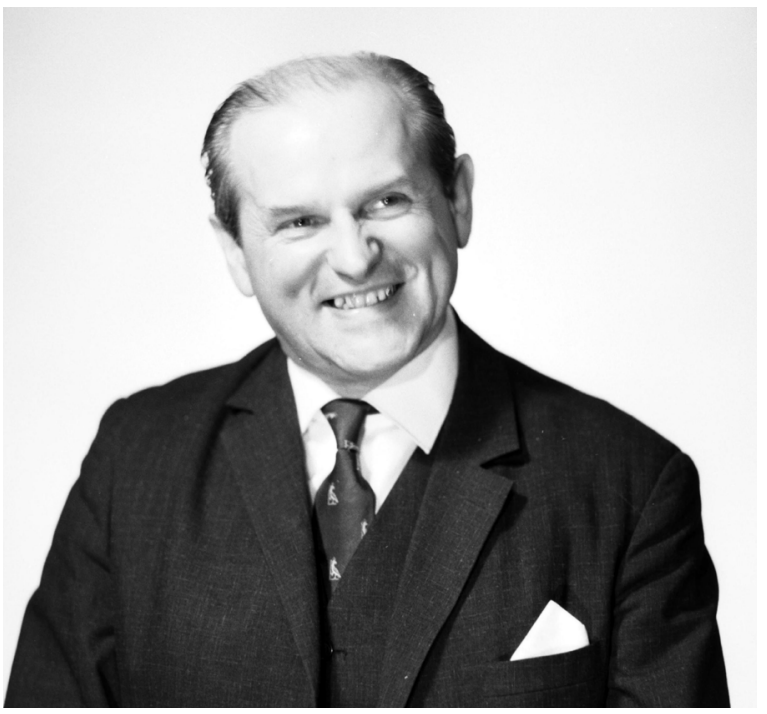

Dr Łukaszczyk's successor for 18 years was Professor Witold J. Rudowski
Afterwards he became the director of the Institute of Haematology, a distinguished member of the Polish Academy of Learning and the Polish Academy of Sciences along with being the chairman of the World College of Surgical Societies, a vice-chairman of the World Health Organization and an honorary doctor at 8 universities. He was a world-renowned scholar and also a humanist and erudite. After many years, he recalled:'My personal connections with the editors of the quarterly Journal of Oncology began in 1956 when I was first appointed the Secretary of the Editorial Office. Unfortunately at this time, the health of the Editor-in-Chief, (Professor Franciszek Łukaszczyk), was worsening who, despite suffering from rapidly advancing radiation sickness, was still interested in assessing and maintaining high levels of excellence in journal's publications. I still remember the day we were discussing the contents of the latest issue of the journal just shortly after I had given him a direct blood transfusion from a donor, whereby the Professor's health condition dramatically improved, but sadly only temporarily.

At that time, the editors did not have their own office. Professor Rudowski recalled: 'I remember the meetings we had of the Editorial Committee in the Institute's Library, in which we established the regulations for accepting papers and the journal's submission criteria. The climate of these meetings, where attendance was not compulsory, was full of objectivity and reliable scientific criticism; this will always remain in my memory'.

The first post-war Editorial Committee consisted of: Professor Józef Laskowski, Dr Hanna Kołodziejska and Dr Henryk Godlewski. The secretary to the editorial team was Dr. Józef Zborzil.

In June 1974, the General Assembly at the XIII Congress of the Polish Society of Oncology entrusted the position of Editor-in-Chief to Professor Hanna Kołodziejska (1914-2004).

She had been working at the Radium Institute from 1943 and after the war, she directed its reconstruction. She took part in the Polish Supply Mission to the USA where she managed to obtain for Poland, amongst other things, $8 \mathrm{~g}$ radium and 10 radiotherapy apparatus. During 1954-80 she was director of the Kraków Branch of the Institute, where she initiated the teaching of oncology for medical students and was the editor and co-author of the first Polish textbook for oncology (1953), along with being the chairman of the PTO's Main Board (1964-74).

The Kraków Branch at Garncarska Street has been the headquarters of the Editorial Office since 1975 and its Editorial Committee significantly expanded. Dr Marek Pawlicki became the scientific secretary. During 1981-86, the academic secretary was Dr Piotr Siedlecki, when the editorial office moved back to Warsaw. After his resignation in 1987, Professor Jerzy Meyza became the new deputy Editor. 


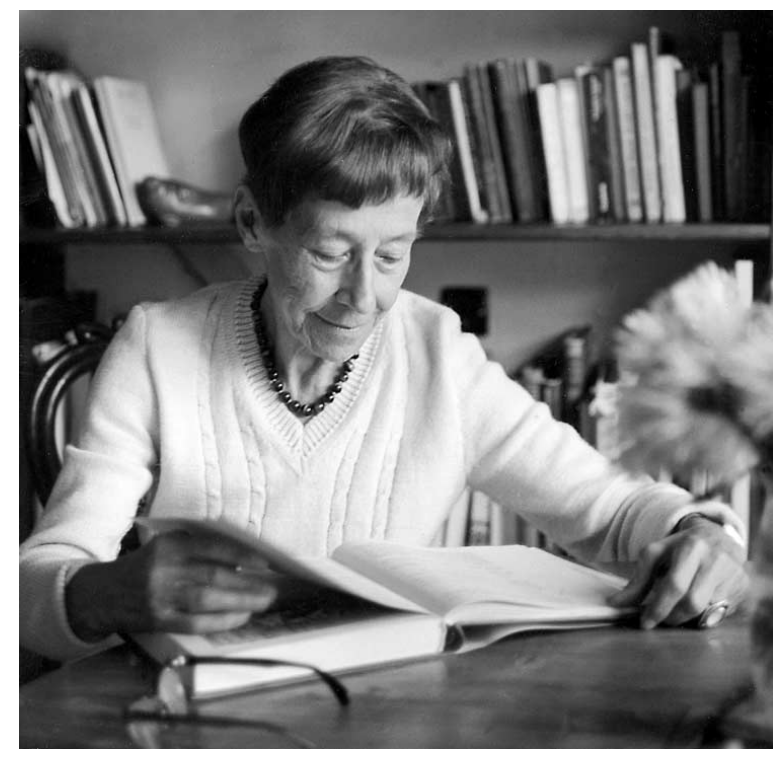

Professor Hanna Kołodziejska was the journal's Editor for four consecutive terms during 1975-90

The most important Polish studies in oncology became published in the journal. The Editorial Committee also initiated publication of a series of articles on the history of the fight against cancer in Poland; 11 papers in all were published on this subject. When summing up her work for the journal, Professor Kołodziejska wrote: 'The papers of the quarterly Nowotwory, their authors and subsequent editorial committees co-created the intellectual foundations for the development of Polish oncology. My direct participation in the long history of this journal has been a great honour to me'.

During 1991-94 Professor Meyza, a surgeon, became the journal's editor in chief.

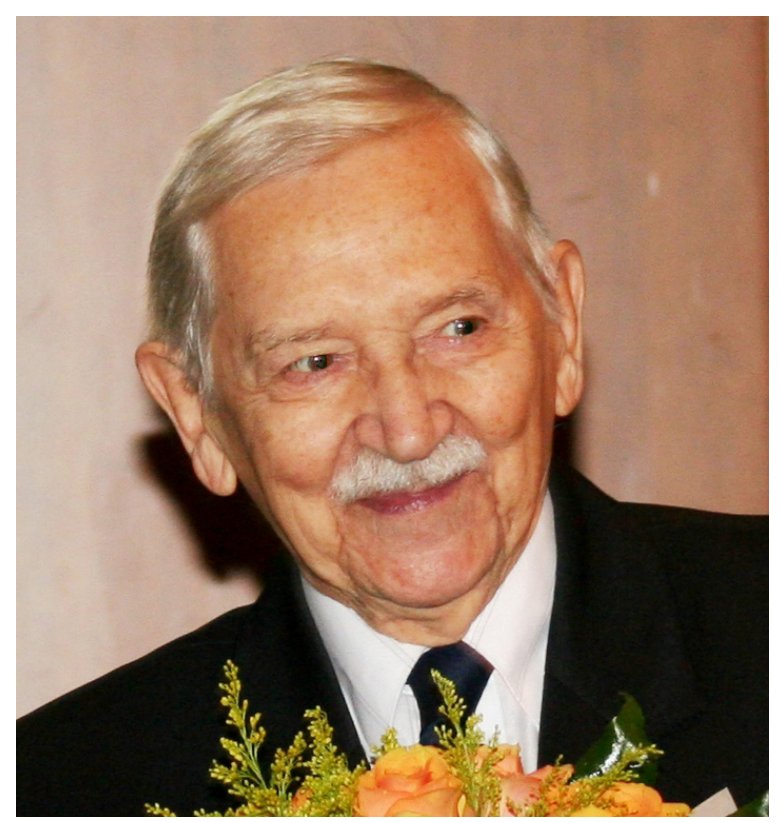

Professor Jerzy Meyza; Editor during 1991-94
This was a difficult period, as the Polski Zakład Wydawnictw Lekarskich (State Department of Medical Publishers) resigned from publishing all scientific medical journals. It was thus necessary to adapt to the new conditions of the nation's transformation. Professor Meyza successfully managed the journal throughout this time, where he also modernised the layout and graphic design.

TOM 42 ZESZYT 2

\section{NOWOTWORY}

\section{ROK JUBILEUSZOWY ONKOLOGII POLSKIEJ 1932-1992}

ROK 1992 KWARTALNIK

Nowotwory cover in 1992-98.

For the first time the editors had their own office, albeit modest and shared (!), in a room on the ground floor of the Institute at Wawelska Street, next to the Radiotherapy Department. In addition to publishing the most important Polish papers on clinical oncology, the Jubilee Year of Polish Oncology (1932-1992) and the 70th anniversary of the quarterly in 1993 were also reported in several memorial articles. When the Centre for Oncology moved to the Ursynow site, the journal was for the first time allotted its own office in a building which housed amongst others, the Scientific Library and a large lecture hall.

Throughout 1991 until 2016, the technical editor was Ms Danuta Sadowska-Osmycka who showed exceptional dedication and professionalism in her work; her role in the smooth functioning of the Editorial office was invaluable.

In 1994, the General Assembly of the PTO nominated Dr Edward Towpik to be the journal's editor, who had previously been deputy editor during Professor Meyza's term of office. 
The number of papers submitted increased and the journal volume was doubled, where in 1998 it was transformed into a bimonthly. The new principles of printing preparation, as recommended by the International Committee of Medical Journal Editors (the so-called Vancouver style), was introduced. They were then described and translated into Polish by the editorial office and appeared for the first time in Polish on the journal's pages. In 1999, the journal's format and layout were substantially changed so as to be in line with global standards.

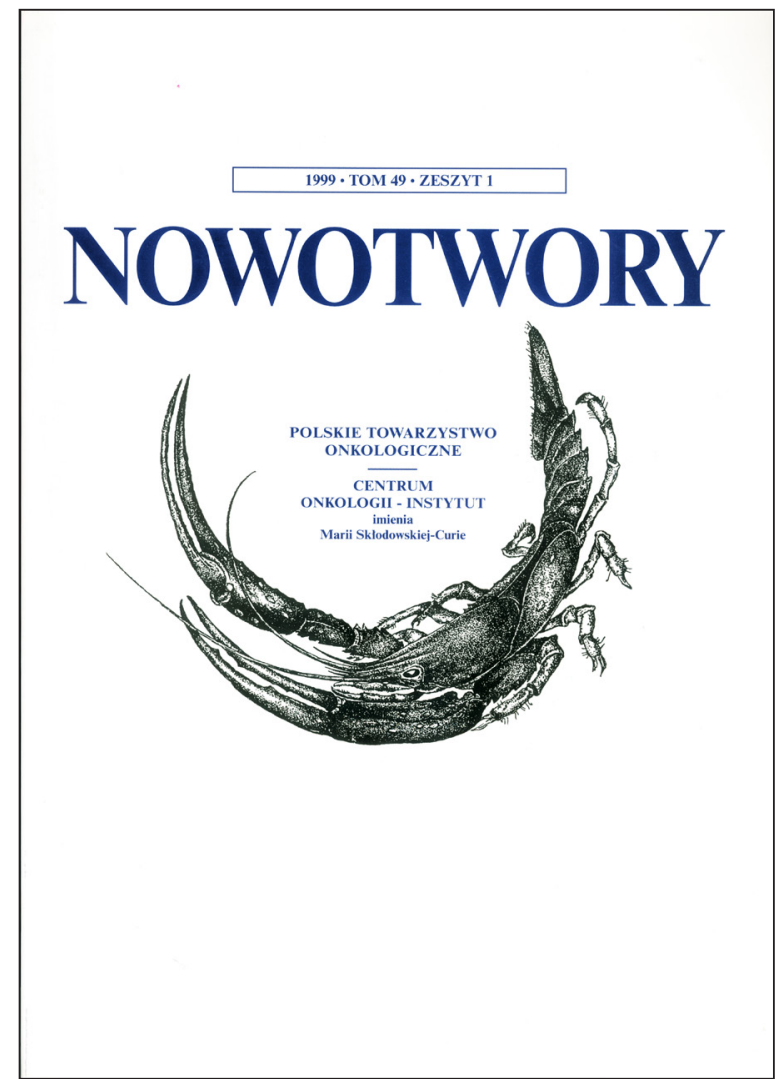

Nowotwory cover after 1999

Because of the need to vacate the current premises, a new journal headquarters was made available in the building for theoretical studies with the kind help of the then Chairman of the Scientific Council of the Centre for Oncology, Professor Jan Steffen.

The next and very important stage in the development of the journal took place in 2001, where a group of foreign experts were invited onto the Editorial Board, thereby transforming it into an International Editorial Board. Publication of original papers in English for an electronic version has now started, the journal name has been expanded and Dr Richard F. Mould from Great Britain has been appointed to the role of Co-Editor.

In addition, supplements are now published. Amongst other things included is a reprint of the first Polish edition of Wilhelm Konrad Roentgen's work on the new type of rays from 1896 and an English-language Maria Skłodowska-Curie Memorial Issue published in 1998 on the 100th anniversary of discovering radium and sent to all major medical collections in the world. Also published was the Memorial Book in honour of Professor Kazimierz Dux (being a de-facto monograph on basic sciences in oncology), a list of papers published in the journal between 1995-99, and a bibliography of papers published during 2000-2004 together with a work by Andrzej Sródka and Edward Towpik on Representatives of the medical sciences; members of the Warsaw Scientific Society during 1907-1952 (Przedstawiciele nauk medycznych - członkowie Towarzystwa Naukowego Warszawskiego $w$ latach 1907-1952). The use of journal supplements has also facilitated the publishing of many habilitation (DSc) dissertations, collections of lectures and summaries from oncological congresses of scientific societies.

An important aspect of historical continuity and the journal's role was entrusting the Editors in preparing for printing, editing and publishing into volumes the proceedings for all four previous Congresses on Polish Oncology (ie. held in Katowice 2002, Poznań 2006, Wrocław 2012 and Łódź 2016). This indeed is a very ennobling acclamation to the tradition of publishing the proceedings for all the four previous pre-war National Anti-Cancer congresses, and also a fifth one held just after the war (Warsaw 1949).

Furthermore, the editors have published other monographs as detailed in the following: To bear testimony to the truth (Dać świadectwo prawdzie...) by Professor Tadeusz Koszarowski, describing more than twenty years of effort, sometimes dramatic, in the struggle leading to the Centre for Oncology being created at the Ursynów site. A collection of outstanding caricature drawings by Professor Leszek Woźniak of the Council of Scientific Consultants members in a bimonthly along with a volume of the memoirs and reflective essays of Witold Rudowski entitled Confessions of a surgeon. Varia litteraria (Spowiedź chirurga. Varia litteraria). An extensive 150-page factfinder of the Maria Skłodowska-Curie Memorial Centre for Oncology was released on the seventieth anniversary of when the Radium Institute opened and also Snipets of memories (Urywki wspomnień) an extensive record of the memories of Professor Tadeusz Koszarowski. There was a true magnum opus by Dr Richard Mould entitled A Radium History Mosaic; being an English-language monograph on the history of using radium in medical practice and also by the same author a Radiation Oncology Bibliography for 1902-2008. Another publication was a photographic album of all former employees of the Radium Institute, the Institute of Oncology during 1932-2009. In 2012, a 350-page volume appeared detailing the history of the Maria Skłodowska-Curie Memorial Radium Institute and the Institute of Oncology in Warsaw on the 80th anniversary of their opening (Materiały do historii Instytutu Radowego i Instytutu Onkologii im. Marii Skłodowskiej-Curie 
w Warszawie w 80 rocznicę otwarcia). Later in 2014, another extremely valuable and extensive work by Richard F. Mould was published, An Annotated X-Ray Bibliography 1896-1945 containing references to nuclear physics, radioactivity \& nuclear medicine. Also in 2014 the same author published a Chronology with special reference to cancer from antiquity in Egypt, Greece \& Rome to Europe and America in the early 20th Century with an annotated bibliography.

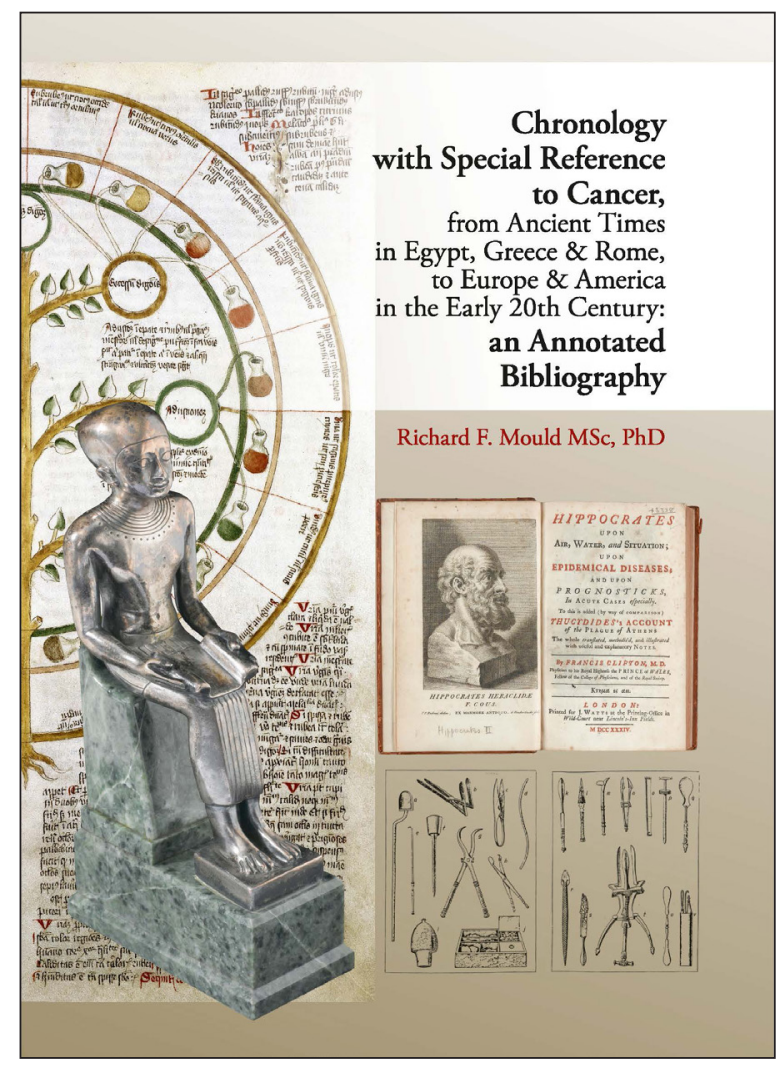

Chronology with special Reference to Cancer... by Nowotwory Co-Editor Richard F. Mould

In the years 2000-2006, professor Edward Towpik was a member of the Editorial Board of European Science Editing the official journal of the European Association of Science Editors (EASE), and in the years 2006-2012, the EASE Board. The editorial staff of Nowotwory co-organized numerous workshops on the preparation of scientific publications, and in 2006 co-organized the EASE conference entitled "The Culture of Science Editing" in Kraków.

A new stage in the journal's history is linked to Professor Jacek Jassem becoming the President of the Polish Society of Oncology. Because of his personal dynamism, he became involved in the Nowotwory Journal of Oncology; both in terms of caring for factual content and form. He initiated changes to the members of the Editorial Board and created new functions: section editors and assigning the publishing role to an experienced company, Via Medica.

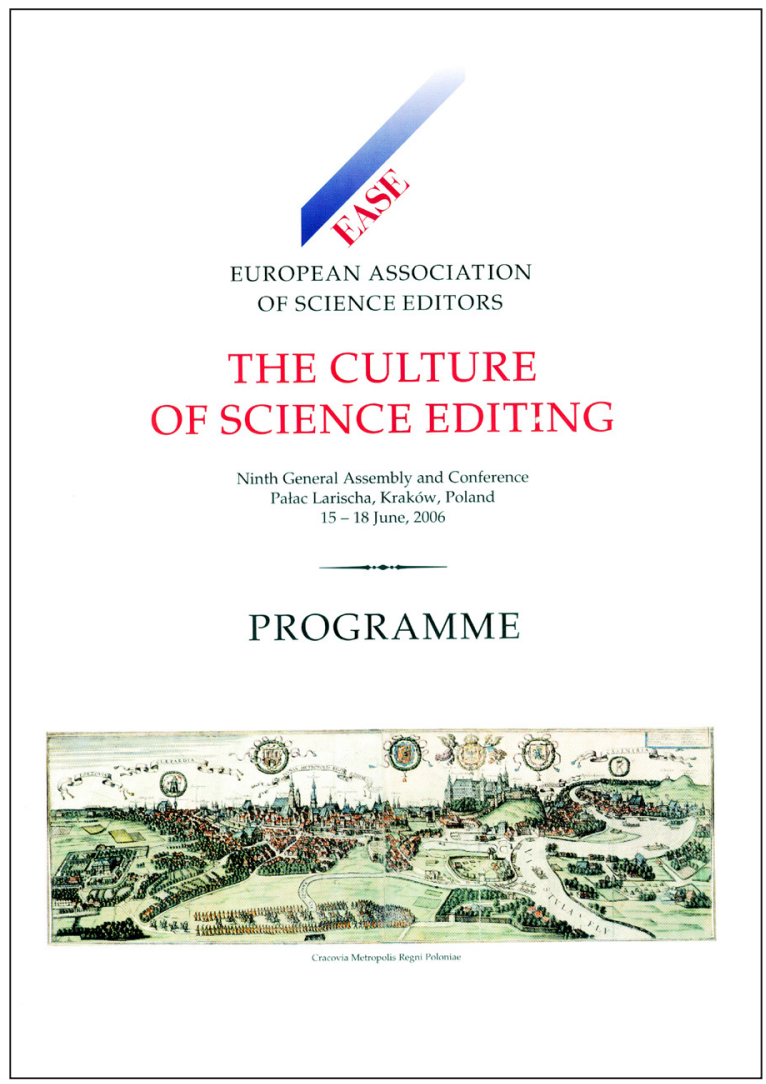

In 2006 Nowotwory editorial staff co-organized the EASE conference entitled "The Culture of Science Editing" in Kraków

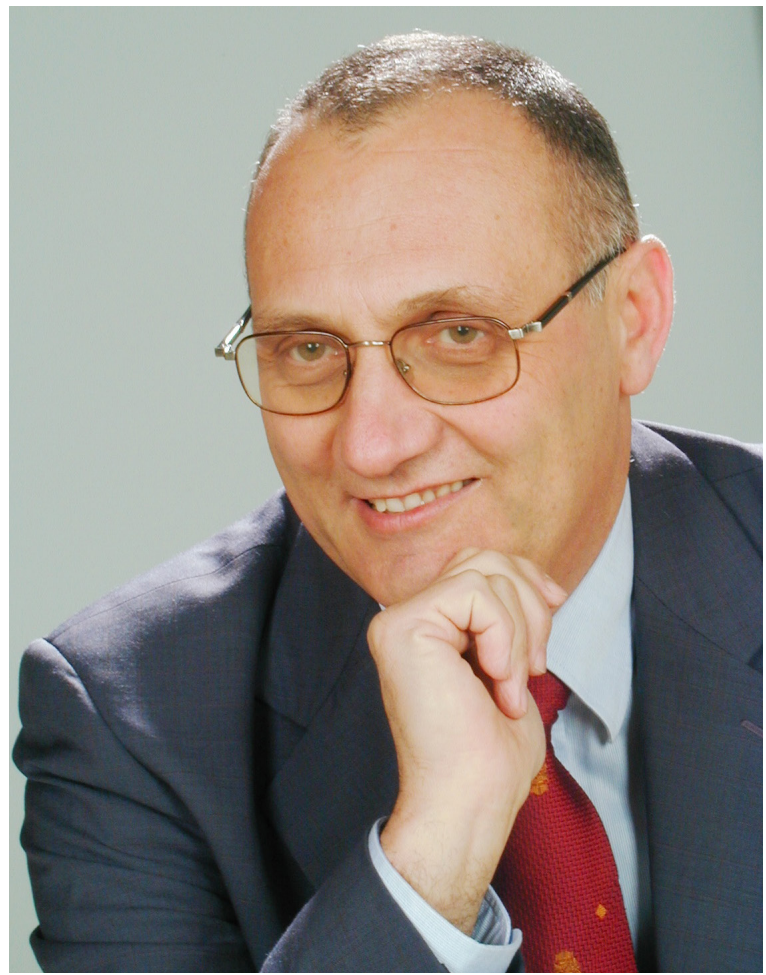

Professor Jacek Jassem; the PTO President during 2010-2014 and initiator of changes and the journal's modernisation 
As a consequence, the journal received a new graphical design. Another initiative by Professor Jacek Jassem was to employ Via Medica together with the journal's editorial office for organising periodic Scientific Conferences of the Nowotwory Journal of Oncology which have the character of Oxford-style debating; this being a novelty for national medical-scientific meetings. These conferences are now held annually in April; the very month in which 95 years ago, the first issue of the Bulletin of the Polish Anti-Cancer Committee had been published.

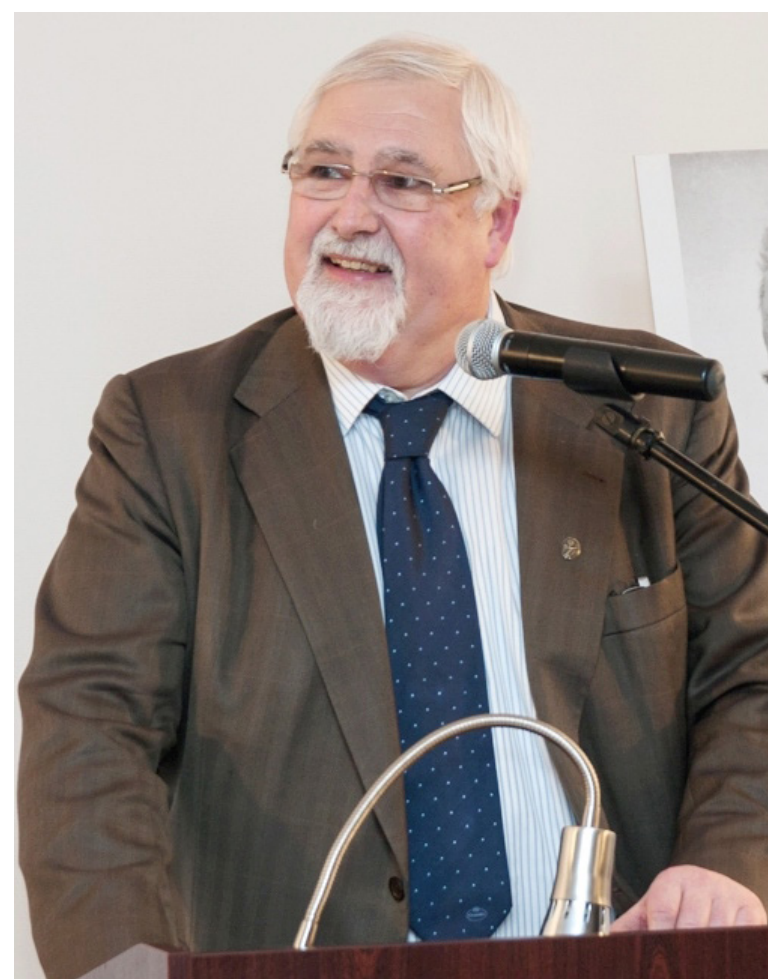

Professor Edward Towpik, Editor in Chief of Nowotwory 1994-2018

In 2014, the Co-Editor's role was assumed by DrWojciech Wysocki MD, DSc from Kraków, at the invitation of the Editor-in-Chief and the President of the PTO. Following approval of the PTO's General Board, the editors decided to provide open access to the journal's content on the Internet in 2016 for all those interested (in an open access form). Thanks to the support of the Count Jakub Potocki Memorial Foundation, the journal is published entirely in English from 2016 onwards under the title of Nowotwory Journal of Oncology. This change is the first step to raise the position of the journal in international repositories of biomedical journals and which has now rapidly increased the influx of submissions from centres abroad. At the same time, in the interests of the national reader, the Polish version is still being distributed to home subscribers; this version being named'Nowotwory - Biuletyn Polskiego Towarzystwa Onkologicznego'.
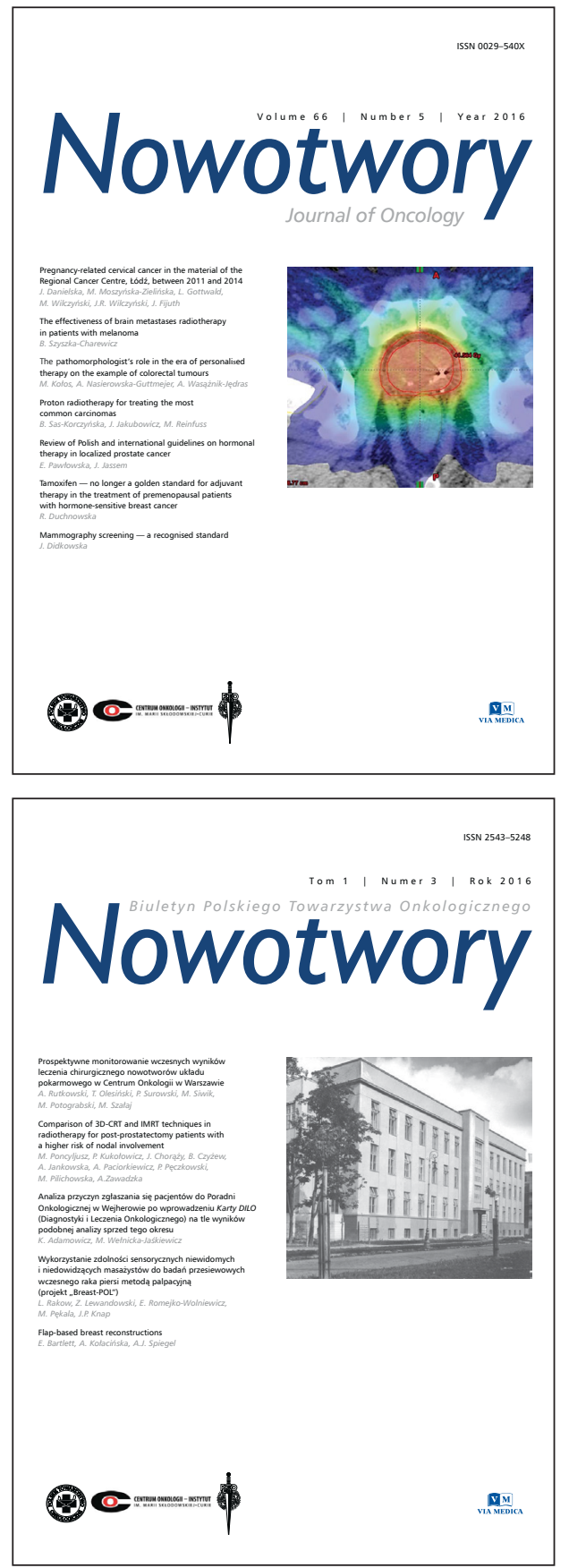

Covers of the Nowotwory Journal of Oncology and Nowotwory Biuletyn Polskiego Towarzystwa Onkologicznego [Nowotwory - Bulletin of the Polish Society of Oncology]

The journal's current managing editor, Ms Aleksandra Towpik, has been energetically involved in gradually introducing new technological solutions to the editorial work. Amongst other things, at the turn of 2017 and 2018, it was decided to launch an electronic system for manuscript submission.

On April 6, during the 6th conference of the 'Oncology Debate', an exhibition devoted to the 95-year history of the journal was opened. During the next months the exhibition 
will be available in the lobby at the entrance to the Centre for Oncology at the Warsaw Ursynów site.

\section{Conflict of interest: none declared}

\section{Wojciech M. Wysocki, MD, PhD}

Maria Skłodowska-Curie Memorial Cancer Centre and Institute of Oncology

Kraków Branch

Department of Surgical Oncology

ul. Garncarska 11, 31-115 Kraków, Poland

e-mail:z5wysock@cyf-kr.edu.pl

Received \& Accepted: 20 Apr 2018

\section{References}

The text, which originally appeared in 2013 to celebrate the journal's 90th anniversary was based on the following works: Vitold Rudowski's 'A page on the history of the Polish Nowotwory 1960; 10: 161-175, Edward Towpik's 'Eighty Years of Cancer (1923-2003)' Nowotwory J Oncol 2003; 53: 293-299, monographs by Jerzy Supady entitled Organisations and institutions for figh ting cancer in Poland during 1906-1939; Lodz 2003, ADI Publishing House, and both pre-war and post-war issues of the Bulletin and Nowotwory.

Previous articles by three consecutive editors were also used which had appeared in a booklet commemorating the 70th anniversary of the journal. These are as follows: Nowotwory 1993; 43: Issue 2 by Witold Rudowski entitled '70 Years of the Polish Journal of Oncology between 1923-1993', in Hanna Kolodziejska's "Quarterly of the Nowotwory from 1974 until 1990" and in Jerzy Meyza's 'Before the next decade's quarterly'. Other articles included were Jakub Chrzanowski's 'The first nationwide Congress on the fight against cancer' in Warsaw 14 December 1924 Biul 1978; 28: 229-231, notes by Edward Towpik 'Recieving the Nowotwory from the printers by Major Dr Wiktor Kalicinski; Editorial secretary in 1929-1939' Nowotwory J Oncol 2003; 53:434-7, 'Proceedings of the IV National Anti-Cancer Congress held in Vilnius 6-8 December 1935' Nowotwory 1997; 47: 133-141, an article by Ludwika Tarłowska and Edward Towpik entitled 'The Radium Institute during the occupation and the Warsaw Uprising' Nowotwory JOncol 2003; 53: 74-86 and the'Memory of Professor Hanna Kołodziejska-Wertheim MD PhD (1914-2004) by Jan Skołyszewski Nowotwory J Oncol 2004; 54: 587-8.

The text has been extended to provide the journal's latest history. 